\title{
ANALISIS TOKSISITAS AKUT KOMBINASI CAPTOPRIL DENGAN REBUSAN DAUN SIRSAK PADA TIKUS GALUR WISTAR
}

\section{Acute Toxicity Analysis Of Captopril Combination With Soursop Leaf Decoction In Wistar Strain Rats}

\author{
Rina Saputri ${ }^{\text {** }}$ \\ Mustaqimah ${ }^{2}$ \\ Ali Rakhman Hakim ${ }^{3}$ \\ ${ }^{*}$ Universitas Sari Mulia, \\ Banjarmasin, Kalimantan \\ Selatan, Indonesia \\ ${ }^{2}$ Universitas Sari Mulia, \\ Banjarmasin, Kalimantan \\ Selatan, Indonesia \\ ${ }^{3}$ Universitas Sari Mulia, \\ Banjarmasin, Kalimantan \\ Selatan, Indonesia \\ *email: \\ rinasaputri@unism.ac.id
}

\section{Kata Kunci:}

Captopril

Daun sirsak

Toksisitas Akut

\section{Keywords: \\ Captopril \\ Soursop leaf \\ Acute Toxicity}

\begin{abstract}
Abstrak
Hipertensi merupakan penyakit degeneratif yang memerlukan terapi seumur hidup. Seiring perkembangan waktu, saat ini masyarakat lebih tertarik untuk mengkonsumsi obat tradisional terutama dengan menggunakan tumbuhan. Selain mengkonsumsi rebusan daun sirsak, masyarakat juga tetap menggunakan obat konvensional untuk membantu mengontrol hipertensi. Kombinasi obat konvensional dan obat tradisional dapat menimbulkan reaksi yang tidak diinginkan jika tidak digunakan dengan dosis yang tepat, salah satunya adalah resiko toksisitas akut. Sampai saat ini belum ada data publikasi yang menunjukkan analisis toksisitas akut kombinasi captopril dengan rebusan daun sirsak. Tujuan dari penelitian adalah mengetahui dosis maksimum kombinasi captopril dan rebusan daun sirsak yang dapat digunakan. Metode yang digunakan pada Penelitian ini merupakan penelitian eksperimental tingkat lanjut dengan desain blok random dengan menggunakan 30 hewan uji yang dibagi menjadi 10 kelompok. Hasil penelitian uji toksisitas akut yang dilakukan tidak menunjukkan adanya kematian hewan uji dalam 24 jam dan sampai 7 hari pengamatan pada semua kelompok percobaan. Hasil uji pengamatan fisik selama 7 hari menunjukkan semua tikus dalam kondisi normal pada semua kelompok percobaan. Kesimpulan dari penelitian ini adalah kombinasi captopril sampai dosis $150 \mathrm{mg} /$ hari (dosis pada manusia sebelum di konversi ke hewan uji) + rebusan daun sirsak dengan dosis efektif $300 \mathrm{ml}$ (dosis pada manusia sebelum di konversi ke hewan uji) tidak menunjukkan adanya kematian dan gejala toksisitas pada hewan uji.
\end{abstract}

\begin{abstract}
Hypertension is a degenerative disease that requires lifelong therapy. Along with the development of time, nowadays people are more interested in consuming traditional medicine, especially by using plants. In addition to consuming soursop leaf decoction, people also continue to use conventional medicine to help control hypertension. The combination of conventional medicine and traditional medicine can cause unwanted reactions if not used in the right dosage, one of which is the risk of acute toxicity. Until now there is no published data showing the acute toxicity analysis of the combination of captopril with soursop leaf decoction. The purpose of the study was to determine the maximum dose of combination of captopril and soursop leaf decoction that could be used. The method used in this study is an advanced experimental study with a random block design using 30 test animals divided into 10 groups. The results of the acute toxicity test conducted did not show any death of the test animals within 24 hours and up to 7 days of observation in all experimental groups. The results of the physical observation test for 7 days showed that all rats were in normal condition in all experimental groups. The conclusion of this study is that the combination of captopril up to a dose of $150 \mathrm{mg} /$ day (dose in humans before conversion to test animals) + soursop leaf decoction with an effective dose of $300 \mathrm{ml}$ (dose in humans before conversion to test animals) did not show any death and symptoms toxicity in test animals.
\end{abstract}




\section{PENDAHULUAN}

Hipertensi merupakan kontributor tunggal utama pada penyakit jantung, gagal ginjal dan stroke jika tidak dikontrol dengan baik.' Berdasarkan data dari riset kesehatan dasar tahun 2018 Angka kejadian hipertensi terus meningkat, khususnya di Kalimantan selatan menduduki posisi pertama. ${ }^{2,3}$ Hipertensi merupakan penyakit degeneratif yang memerlukan terapi seumur hidup. Seiring perkembangan waktu, saat ini masyarakat lebih tertarik untuk mengkonsumsi obat tradisional terutama dengan menggunakan tumbuhan. Salah satu tumbuhan yang sering digunakan masyarkat untuk mengatasi hipertensi adalah rebusan daun sirsak. Berdasarkan hasil uji pra klinis rebusan daun sirsak sebanyak $300 \mathrm{ml}$ per hari efektif untuk menurunkan tekanan darah. ${ }^{4-11}$ Selain mengkonsumsi rebusan daun sirsak, masyarakat juga tetap menggunakan obat konvensional untuk membantu mengontrol hipertensi. Salah satu obat konvensional yang banyak di konsumsi masyarkat adalah captopril. Dosis captoril dapat berbeda pada individu pasien karena harus disesuiakan dengan tekanan darah pasien tersebut. Dosis captopril untuk mengatasi hipertensi dimulai dengan dosis 12,5 $25 \mathrm{mg} 2-3 \times$ sehari dan dapat ditingkatkan sampai dosis maksimal $150 \mathrm{mg} /$ hari. $^{12-15}$

Penggunaan obat hipertensi di masyarakat masih banyak yang tidak sesuai dengan resep dokter, masyarakat sering mengkonsumsi berdasarkan pengalaman yang dialaminya atau orang di sekitarnya, sehingga beresiko tidak mendapatkan efek terapi yang optimal dan juga sangat memungkinkan terjadinya reaksi obat yang tidak diinginkan. ${ }^{4}$ Berdasarkan beberapa hasil penelitian sebelumnya menunjukkan baik ekstrak metanol ataupun etanol daun sirsak memiliki potensi toksisitas terhadap larva Artemia Salina Leach dan pada mencit. Sediaan yang umum dikonsumsi masyarakat adalah rebusan daun sirsak. ${ }^{16-18}$ Kombinasi obat konvensional dan obat tradisional dapat menimbulkan reaksi yang tidak diinginkan jika tidak digunakan dengan dosis yang tepat, salah satunya adalah resiko toksisitas akut. Sampai saat ini belum ada data publikasi yang menunjukkan analisis toksisitas akut kombinasi captopril dengan rebusan daun sirsak. Evaluasi toksisitas dari kombinasi obat ini penting untuk dilakukan dengan mempertimbangakn perlindungan kesehatan masyarakat karena paparan senyawa kimia yang dapat menyebabkan reaksi yang tidak diinginkan pada masyarakat. ${ }^{19}$

\section{METODOLOGI}

I. Metode Penelitian

Penelitian ini merupakan penelitian eksperimental tingkat lanjut dengan desain blok random. Sampel dibagi menjadi 10 kelompok.

2. Alat dan Bahan Penelitian

Alat yang digunakan dalam penelitian ini adalah pipet tetes, pipet Ukur, Labu Ukur, gelas ukur, sonde oral, panci, kompor, timbangan analitik, dan kandang tikus.

Bahan yang digunakan dalam penelitian ini adalah, Captopril, Daun sirsak, tikus galur wistar, Aquadest, sekam dan Pangan tikus.

3. Teknik pengumpulan data'

Data yang dikumpulkan pada penelitian ini adalah data primer dari hasil pengamatan langsung kepada hewan uji. Data yang diperoleh berupa data kuantitatif dan kualitatif. Data kuantitatif didapatkan dari jumlah hewan uji yang mati dan data kualitatif didapatkan dari kondisi fisik hewan uji.

4. Prosedur Uji Toksisitas Akut

a. Pengolahan Larutan induk Captopril Berdasarkan teori dosis maksimal captopril per hati pada pasien hipertensi adalah 150 $\mathrm{mg}$, sehingga pada penelitian ini dibuat 3 konsentrasi larutan induk yaitu $25 \mathrm{mg}, 100$ $\mathrm{mg}$, dan $150 \mathrm{mg}$, masing - masing konsentrasi dibuat sebanyak $20 \mathrm{ml}$.

b. Pengolahan Rebusan Daun sirsak 
Sebanyak 20 lembar daun sirsak direbus dengan 4 gelas air $( \pm 1000 \mathrm{ml})$, kemudian ditunggu sampai tersisa setengahnya $( \pm 500$ $\mathrm{ml}$ ). Berdasarkan hasil penelitian dosis efektif rebusan daun sirsak adalah $300 \mathrm{ml} /$ hari pada manusia.

c. Pembagian kelompok Percobaan

Pada penelitian ini percobaan dibagi menjadi I0 kelompok, yang terdiri dari:

Tabel I : pembagian kelompok hewan uji

\begin{tabular}{|c|c|}
\hline Kelompok & Perlakuan \\
\hline Kontrol & Aquadest \\
\hline $\mathrm{Pl}$ & Captopril dosis $25 \mathrm{mg}$ \\
\hline $\mathrm{P} 2$ & Captopril dosis $50 \mathrm{mg}$ \\
\hline P3 & Captopril dosis $150 \mathrm{mg}$ \\
\hline P4 & $\begin{array}{l}\text { Captopril dosis } 25 \mathrm{mg}+\text { rebusan daun } \\
\text { sirsak } 300 \mathrm{ml} \text { yang diberikan secara } \\
\text { bersamaan }\end{array}$ \\
\hline P5 & $\begin{array}{l}\text { Captopril dosis } 50 \mathrm{mg}+\text { rebusan daun } \\
\text { sirsak } 300 \mathrm{ml} \text { yang diberikan secara } \\
\text { bersamaan }\end{array}$ \\
\hline P6 & $\begin{array}{l}\text { Captopril dosis } 150 \mathrm{mg}+\text { rebusan daun } \\
\text { sirsak } 300 \mathrm{ml} \text { yang diberikan secara } \\
\text { bersamaan }\end{array}$ \\
\hline P7 & $\begin{array}{l}\text { Captopril dosis } 25 \mathrm{mg}+\text { rebusan daun } \\
\text { sirsak } 300 \mathrm{ml} \text { yang diberikan jeda waktu } 2 \\
\text { jam }\end{array}$ \\
\hline P8 & $\begin{array}{l}\text { Captopril dosis } 50 \mathrm{mg}+\text { rebusan daun } \\
\text { sirsak } 300 \mathrm{ml} \text { yang diberikan jeda waktu } 2 \\
\text { jam }\end{array}$ \\
\hline P9 & $\begin{array}{l}\text { Captopril dosis } 150 \mathrm{mg}+\text { rebusan daun } \\
\text { sirsak } 300 \mathrm{ml} \text { yang diberikan jeda waktu } 2 \\
\text { jam }\end{array}$ \\
\hline
\end{tabular}

d. Pengamatan Kondisis Fisik dan Kematian Hewan Uji

Pada uji toksisitas akut, pengamatan kondisi fisik dan kematian dilakukan dalam 24 jam pertama, dan dilanjutkan 7 - 14 hari untuk melihat toksisitas yang tertunda. Pada penelitian ini pengamatan dilakukan selama 7 hari.

\section{HASIL DAN PEMBAHASAN}

Penelitian ini menggunakan 30 ekor tikus galur wistar, yang dibagi menjadi 10 kelompok percobaan. Secara umum kelompok percobaan dibagi menjadi empat kelompok, yaitu kelompok kontrol yang menggunakan aquadest, kelompok kontrol yang menggunakan captopril, kelompok kombinasi captoril dan rebusan daun sirsak yang diberikan bersama - sama, dan kelompok kombinasi captopril dengan rebusan daun sirsak yang diberikan terpisah dengan jeda waktu 2 jam, kemudian secara khusus masing - masing kelompok dibagi lagi menjadi kelompok lainnya dengan menggunakan variasi dosis captopril dari dosis minimal sampai dosis maksimal perhari, dan menggunakan dosis rebusan daun sirsak yang sama yaitu $300 \mathrm{ml} /$ hari pada manusia. Dosis yang digunakan merupakan dosis yang telah terbukti mampu menurunkan tekanan darah, akan tetapi belum terbukti apakah dapat menimbulkan toksisitas jika diberikan bersama - sama.

Hasil penelitian uji toksisitas akut yang dilakukan tidak menunjukkan adanya kematian hewan uji dalam 24 jam dan sampai 7 hari pengamatan pada semua kelompok percobaan, sehingga dapat dikatakan penggunaan kombinasi captopril sampai $150 \mathrm{mg} /$ hari dengan rebusan daun sirsak $300 \mathrm{ml} /$ hari tidak toksik. Hasil pengamatan dapat dilihat pada tabel 2 :

Tabel 2. Hasil pengamatan kematian hewan uji dalam 24 jam dan sampai 7 hari pengamatan

\begin{tabular}{|c|c|c|c|}
\hline $\begin{array}{c}\text { Kelompo } \\
\mathrm{k}\end{array}$ & Perlakuan & $\begin{array}{l}\text { Jumlah } \\
\text { sampel }\end{array}$ & $\begin{array}{c}\text { Jumlah } \\
\text { Tikus yang } \\
\text { mati }\end{array}$ \\
\hline Kontrol & Aquadest & 3 & 0 \\
\hline PI & $\begin{array}{l}\text { Captopril } \\
\text { dosis } 25 \mathrm{mg}\end{array}$ & 3 & 0 \\
\hline P2 & $\begin{array}{l}\text { Captopril } \\
\text { dosis } 50 \mathrm{mg}\end{array}$ & 3 & 0 \\
\hline P3 & $\begin{array}{l}\text { Captopril } \\
\text { dosis } 150 \mathrm{mg}\end{array}$ & 3 & 0 \\
\hline
\end{tabular}




\begin{tabular}{|c|c|c|c|}
\hline P4 & $\begin{array}{l}\text { Captopril } \\
\text { dosis } 25 \mathrm{mg}+ \\
\text { rebusan daun } \\
\text { sirsak } 300 \mathrm{ml} \\
\text { yang } \\
\text { diberikan } \\
\text { secara } \\
\text { bersamaan }\end{array}$ & 3 & 0 \\
\hline P5 & $\begin{array}{l}\text { Captopril } \\
\text { dosis } 50 \mathrm{mg}+ \\
\text { rebusan daun } \\
\text { sirsak } 300 \mathrm{ml} \\
\text { yang } \\
\text { diberikan } \\
\text { secara } \\
\text { bersamaan }\end{array}$ & 3 & 0 \\
\hline P6 & $\begin{array}{l}\text { Captopril } \\
\text { dosis } 150 \mathrm{mg} \\
+\quad \text { rebusan } \\
\text { daun sirsak } \\
300 \mathrm{ml} \text { yang } \\
\text { diberikan } \\
\text { secara } \\
\text { bersamaan }\end{array}$ & 3 & 0 \\
\hline P7 & $\begin{array}{l}\text { Captopril } \\
\text { dosis } 25 \mathrm{mg}+ \\
\text { rebusan daun } \\
\text { sirsak } 300 \mathrm{ml} \\
\text { yang } \\
\text { diberikan jeda } \\
\text { waktu } 2 \text { jam }\end{array}$ & 3 & 0 \\
\hline P8 & $\begin{array}{l}\text { Captopril } \\
\text { dosis } 50 \mathrm{mg}+ \\
\text { rebusan daun } \\
\text { sirsak } 300 \mathrm{ml} \\
\text { yang diberikan } \\
\text { jeda waktu } 2 \\
\text { jam }\end{array}$ & 3 & 0 \\
\hline P9 & $\begin{array}{l}\text { Captopril } \\
\text { dosis } 150 \mathrm{mg} \\
+\quad \text { rebusan } \\
\text { daun sirsak } \\
300 \mathrm{ml} \text { yang } \\
\text { diberikan jeda } \\
\text { waktu } 2 \text { jam }\end{array}$ & 3 & 0 \\
\hline
\end{tabular}

Hasil uji pengamatan fisik selama 7 hari menunjukkan semua tikus dalam kondisi normal pada semua kelompok percobaan, sehingga dapat dikatakan penggunaan kombinasi captopril sampai $150 \mathrm{mg} /$ hari dengan rebusan daun sirsak $300 \mathrm{ml} / \mathrm{hari}$ tidak menimbulkan perubahan kondisi fisik hewan uji. Hasil pengamatan dapat dilihat pada tabel 3 :

Tabel 3. Hasil pengamatan kondisi fisik hewan uji dalam 24 jam dan sampai 7 hari pengamatan perilaku, gerakan, ukuran pupil,

Kelompok pernafasan, saluran cerna

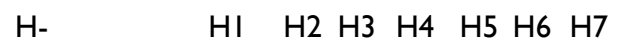

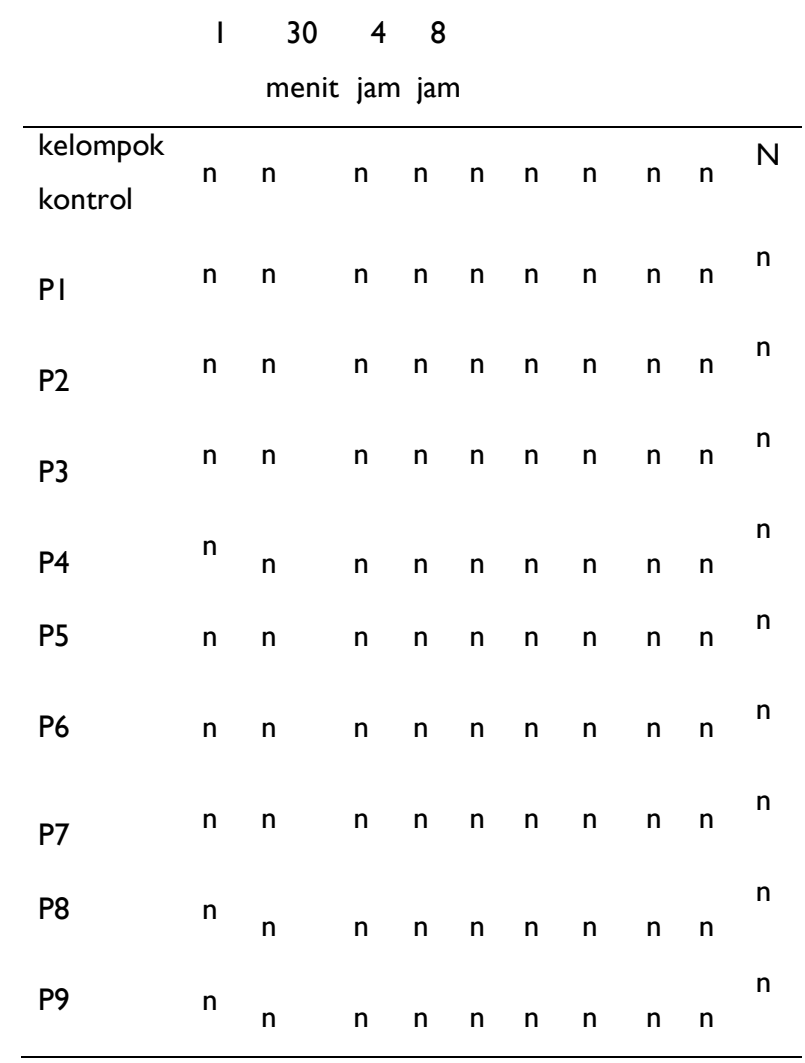

\section{KESIMPULAN}

Berdasarkan hasil penelitian tersebut dapat disimpulkan bahwa kombinasi captopril sampai dosis $150 \mathrm{mg} /$ hari (dosis pada manusia sebelum di konversi ke hewan uji) + rebusan daun sirsak dengan dosis efektif $300 \mathrm{ml}$ (dosis pada manusia sebelum di konversi ke hewan uji) tidak menunjukkan adanya kematian dan gejala toksisitas pada hewan uji.

\section{UCAPAN TERIMA KASIH}

Ucapan terima kasih diberikan kepada Kemendikbudristek dan Universitas Sari Mulia yang telah memfasilitasi kegiatan penelitian ini.

\section{REFERENSI}

I. Zhou, D., Xi, B., Zhao, M., Wang, L., \& Veeranki, S. P. (20I8). Uncontrolled hypertension increases risk of all-cause and cardiovascular disease mortality in US adults: the NHANES III Linked Mortality Study. Scientific reports, 8(I), I-7.

2. Kementrian Kesehatan RI. 2013. Riset Kesehatan Dasar. Jakarta: Badan Penelitian dan 
Pengembangan Kesehatan.

3. Kementrian Kesehatan RI. 2018. Profil Kesehatan Indonesia 20I7. Jakarta: Kemenkes RI.

4. Paramita S, Dkk. 2017. Pola Penggunaan Obat Bahan Alam Sebagai Terapi Komplementer Pada Pasien Hipertensi Di Puskesmas. Jurnal Sains Dan Kesehatan. 2017. Vol I. No 7. P-Issn: 2303-0267, E-Issn: 2407-6082

5. Jacob A. 2016. Efektifitas Pemberian Air Rebusan Daun Sirsak Terhadap Penurunan Tekanan Darah Pada Penderita Hipertensi Di Desa Motoling I.

6. JACOB, A. S., Ake, J., \& Silva, M. (2016). Efektifitas Pemberian Air Rebusan Daun Sirsak Terhadap Penurunan Tekanan Darah Pada Penderita Hipertensi Di Desa Motoling I (Doctoral Dissertation, Universitas Katolik De La Salle).

7. Coria-Téllez, A. V., Montalvo-Gónzalez, E., Yahia, E. M., \& Obledo-Vázquez, E. N. (20I8). Annona muricata: A comprehensive review on its traditional medicinal uses, phytochemicals, pharmacological activities, mechanisms of action and toxicity. Arabian Journal of chemistry, I I(5), 662-691.

8. Sukandar, E. Y., Sigit, J. I., \& Dewi, N. P. (20/4). Uji Efek Penurunan Tekanan Darah Ekstrak Etanol Daun Sirsak (Annona muricata L.) pada Tikus Wistar Jantan. Acta Pharmaceutica Indonesia, 39, $4 \mid-44$.

9. Patel S, Patel Jk. (20I6). A Review On A Miracle Fruits Of Annona Muricata. Journal Of Pharmacognosy And Phytochemistry. 5(1): 137148.

10. Safruddin, Alfira N. 2017. Efektivitas Daun Sirsak Terhadap Penurunan Tekanan Darah Pada Penderita Hipertensi Di Wilayah Kerja Puskesmas Balibo Kabupaten Bulukumba. Jurnal Kesehatan Panrita Husada | Vol. 2 No.2

II. Nurhanifah F. 2013. Perbandingan Pengaruh Daun Sirsak (Annona Muricata L) Terhadap Penurunan Tekanan Darah Pada Penderita Hipertensi Derajat I Dan Hipertensi Derajat 2 Di Wilayah Kerja Puskesmas Tanjung Pati Kabupaten Lima Puluh Kota Tahun 2013.
12. FITRAH, N. (20I3). Perbandingan Pengaruh Daun Sirsak (Annona Muricata L) Terhadap Penurunan Tekanan Darah Pada Penderita Hipertensi Derajat I Dan Hipertensi Derajat 2 Diwilayah Kerja Puskesmas Tanjung Pati Kabupaten Lima Puluh Kota Tahun 2013 (Doctoral dissertation, Universitas Andalas).

13. Nwokocha Cr, Owu Du, Gordon A, Thaxter K, Mccalla G, Ozolua Ri, Young L. (20I2). Possible Mechanisms Of Action Of The Hypotensive Effect Of Annona Muricata (Soursop) In Normotensive Sprague-Dawley Rats. Pharmaceutical Biology. 50(I I): |436-|44I.

14. James, P. A., Suzanne, O.M.D., Barry, L.C., William, C.C., Cheryl, D.H., Joel, H., Et Al. 2013. 2014 Evidence-Based Guideline For The Management Of High Blood Pressure In Adults Report From The Panel Members Appointed To The Eighth Joint National Committee (Jnc 8). Jama (Journal Of American Medical Association).

15. Chen YJ, Li LJ, Tang WL, Song JY, Qiu R, Li Q, Xue $\mathrm{H}$, Wright JM. First-line drugs inhibiting the renin angiotensin system versus other first-line antihypertensive drug classes for hypertension. Cochrane Database Syst Rev. 2018 Nov 14;। I:CD008170.

16. Gan, Z., Huang, D., Jiang, J., Li, Y., Li, H., \& Ke, Y. (20I8). Captopril alleviates hypertension-induced renal damage, inflammation, and NF-kB activation. Brazilian Journal of Medical and Biological Research, 5 I.

17. Aberg, J.A., Lacy, C., Amstrong, L., Goldman, M. and Lance, L.L., 2013, Drug Information Handbook 22th Edition, American Pharmacist Association.

18. Hanifah NZ. 20I5. Uji Toksisitas Akut Ekstrak Metanol Daun Sirsak (Annona muricata L) Terhadapa Larva Artemia salina Leach dengan metode Brine Shrimp Lethality Test (BSLT).

19. Hairunnisah I. 2019. Uji Toksisitas Akut Ekstrak Etanol Daun Sirsak (Annona muricata L.) Terhadap Hati Mencit. Jurnal of Pharmacautical World. 
20. Zuddin RR, Abadi H. 2016. Uji Toksisitas Ekstrak Etanol Daun Sirsak (Annona muricata L.) Pada Larva Udang (Artemia Salina Leach.)

21. Jothy SL, Zakaria Z, Chen Y, Lau YL, Latha LY, Sasidharan, 2011. Acute Oral Toxicity of Methanolic seed Extract of Cassia fistula in Mice.

Molecules Vol $16: 5268$ - 5282. 